neurology and more fundamental research was being undertaken with the help of Government funds in the research council's establishments and in universities.

In reply to questions in the House of Commons on November 23 regarding the future of inland waterways, the Joint Parliamentary Secretary to the Ministry of Transport, Mr. J. Morris, declined to add to what he had said in a debate on November 18 which noted the annual report and accounts of the British Waterways Board for 1965, and the relevant chapter in the statement on transport policy. It was not intended to have a separate waterways trust and there were very good reasons for having the management of both the commercial and amenity sides of the network under one roof. Mr. Morris said in the debate that the Government would be ready to consider on their merits proposals for modest developments or improvements that the board might recommend from time to time, provided they showed real prospects of economic return. It was hoped to devise a standing consultation machinery, and current consultations with interested bodies were expected to provide some useful leads. The general intention was to introduce a major Transport Bill during the next session which he hoped would cover many facets of the transport field.

\section{Royal Society Medals}

Aт the anniversary meeting of the Royal Society on November 30 the following medals were awarded: the Copley Medal, to SIR LAwrence BRAGG, formerly Fullerian professor of chemistry and director of the Royal Institution; the Rumford Medal, to Sir Wilutam Penney, chairman of the Atomic Energy Authority; Royal Medals, to Mr. J. A. RATCLIFFE, formerly director of the Radio and Space Research Station, Science Research Council; DR. F. YAtes, deputy director and head of the Department of Statistics and Agricultural Research Statistical Service at Rothamsted Experimental Station; and Mr. C. S. Cockerell, designer of the hovercraft; the Davy Medal, to SIR EWART Jones, Waynflete professor of chemistry in the University of Oxford; the Darwin Medal, to Professor H. M. Fox, emeritus professor of zoology in the University of London; the Hughes Medal, to Professor N. Kemmer, Tait professor of natural philosophy in the University of Edinburgh; the Leverhulme Medal, to Mr. A. A. C. Issigonis, motor-car designer, British Motor Corporation, Ltd.

\section{University News:}

Bristol

Dr. H. TAJfeL, at present lecturer in social psychology in the University of Oxford, has been appointed to the chair of psychology, and Dr. N. Thompson, reader in physics and assistant director of the H. H. Wills Physics Laboratory, has been appointed to the additional chair of physics. Professor J. P. Hudson, at present professor of horticulture in the University of Nottingham, has been appointed to the directorship of the Long Ashton Research Station and to the chair in the Department of Agriculture and Horticulture as from August 1, 1967, on the retirement of Professor H. G. H. Kearns.

Hongkong

Professor H. C. H. Gurney, at present professor of civil and structural engineering, University College of South Wales and Monmouthshire, has been appointed to the chair of mechanical engineering, and Dr. D. S. Payne, at present senior lecturer in chemistry in the University of Glasgow, has been appointed to the chair of chemistry.

Sussex

Dr. A. Korner, at present lecturer in biochemistry in the University of Cambridge, has been appointed to the chair of biochemistry.

\section{Appointments}

Dr. B. G. Dickins, who became director general of guided weapons in 1962, has been appointed deputy controller of guided weapons by the Minister of Aviation.

\section{Announcements}

Dr. George E. Palade, professor of cytology in the Rockefeller University, has been awarded the $\$ 6,500 \mathrm{~T}$. Duckett Jones Memorial Award of the Helen Hay Whitney Foundation, of New York City, in recognition of his contribution to the knowledge of cellular structure and function. He has also been awarded the 1966 Albert Lasker Modical Research Award for his basic research on the cell.

The Colworth Medal, which has been donated by the Unilever Research Laboratory, is awarded annually by the Biochemical Society to the most promising young British biochemist, and nominations are invited for the award of this medal for 1966. Further information can be obtained from the Honorary Secretary, the Biochemical Society, 20 Park Crescent, London, W.1.

A FUND has been established in momory of the Danish biochemist, Kaj Linderstrøm-Lang, with the purpose of awarding a prize consisting of a gold medal and D. kr. 10,000 for achievements in the field of biochemistry. The first prize has been awarded to Walter Kauzmann, of the Frick Chemical Laboratory, Princeton University, for his work on optical rotation and its application to protein chemistry, and of his elucidation of the forces responsible for maintaining the native conformation of proteins.

A ONE-DAY meeting on "Field-ion Microscopy", arranged by the Electron Microscopy and Analysis Group of the Institute of Physics and the Physical Society, will be held at the University of Cambridge on March 20. Further information can be obtained from the Meetings Officer, The Institute of Physics and the Physical Society, 47 Belgrave Square, London, S.W.1.

The Science of Science Foundation has arranged three seminars on the planning of research and development on January 25, February 22 and March 22, 1967, at 4 p.m., at the Department of Electrical Engineering, Imperial College, London. The seminars will be opened by Dr. Douglas Hill, Sir Charles Goodeve and Dr. L. Rotherham, respectively. Further details can be obtained from the Science of Science Foundation, c/o The Ciba Foundation, 41 Portland Place, London, W.1.

The Winter Gordon Research Conferences will be held in Santa Barbara, California, at the Miramar Hotel during January 23-February 3. Those who wish to attend must send their applications in duplicate on the standard form which can be obtained from the office of the director. These applications will be reviewed by the Conference Committee and a rogistration card sent to those selected. The number of participants is limited to approximately one hundred at each conference. A fixed fee of $\$ 125$ will be charged for resident scientists, and it is hoped all will live at the conference location. Accommodation is available for wives and children over 12 years of age. The first conference, which deals with "Electrochomistry", will take place during January 23-27, and the socond, on "Polymers", during January 30-February 3. Application forms and further information can be obtained from Dr. W. George Parks, Gordon Research Conferences, University of Rhode Island, Kingston, Rhode Island. 